\title{
Hydrogen peroxide electrogeneration in gas diffusion electrode nanostructured with $\mathrm{Ta}_{2} \mathrm{O}_{5}$
}

\author{
Jussara F. Carneiro ${ }^{a}$, Robson S. Rocha ${ }^{a}$, Peter Hammer ${ }^{b}$, R. Bertazzolic ${ }^{c}$, M.R.V. Lanza ${ }^{a} *^{*}$ \\ a Instituto de Química de São Carlos, Universidade de São Paulo, Avenida Trabalhador São Carlense 400, 13566-590 São Carlos, SP, Brazil \\ b Instituto de Química, Universidade Estadual Paulista, Rua Professor Francisco Degni 55, 14800-060 Araraquara, SP, Brazil \\ ${ }^{c}$ Faculdade de Engenharia Mecânica, Universidade Estadual de Campinas, Rua Mendeleyev 200, 13083-860 Campinas, SP, Brazil
}

\section{A R T I C L E I N F O}

\section{Article history:}

Received 30 December 2015

Received in revised form 23 February 2016

Accepted 9 March 2016

Available online 11 March 2016

\section{Keywords:}

Tantalum oxide

Oxygen reduction reaction

Hydrogen peroxide electrogeneration

Gas diffusion electrode

\begin{abstract}
A B S T R A C T
Highly efficient $\mathrm{H}_{2} \mathrm{O}_{2}$ electrogeneration is required in the Advanced Oxidation Process for organic wastewater treatment. However, the development of more efficient catalytic particles used in gas diffusion electrodes (GDEs) to enable the oxygen reduction reaction through two-electron transfer is still of great importance. The performance of the $\mathrm{Ta}_{2} \mathrm{O}_{5}$ nanoparticles on carbon black in catalyzing the ORR was evaluated using rotating ring-disk electrode. The current efficiency for $\mathrm{H}_{2} \mathrm{O}_{2}$ electrogeneration on $\mathrm{Ta}_{2} \mathrm{O}_{5} / \mathrm{C}$ catalyst is $83.2 \%$ whereas carbon black exhibits $65.3 \%$. GDEs were constructed using carbon black either unmodified or modified with $\mathrm{Ta}_{2} \mathrm{O}_{5}$ nanoparticles. The modified GDE produces $27.9 \mathrm{mg} \mathrm{L}^{-1}$ of $\mathrm{H}_{2} \mathrm{O}_{2}$, while the unmodified GDE generates $19.1 \mathrm{mg} \mathrm{L}^{-1}$ of $\mathrm{H}_{2} \mathrm{O}_{2}$. Furthermore, the energy consumption for the $\mathrm{H}_{2} \mathrm{O}_{2}$ electrogeneration is lower in modified than in unmodified GDE ( $15.0 \mathrm{kWh}$ vs. $18.8 \mathrm{kWh}$ ). The high performance of the GDE $\left(\mathrm{Ta}_{2} \mathrm{O}_{5} / \mathrm{C}\right)$ renders it a viable alternative cathode in the electrochemical treatment of wastewaters.
\end{abstract}

(c) 2016 Elsevier B.V. All rights reserved.

\section{Introduction}

Advanced oxidation processes (AOPs) constitute a promising technology for the treatment of wastewaters. These processes involve the generation of highly reactive species, particularly the hydroxyl radical $(\bullet \mathrm{OH})$. The $\bullet \mathrm{OH}$ exhibits strong oxidizing power in aqueous phase due to its high standard reduction potential $(+2.73 \mathrm{~V}$ vs SHE) [1]. Therefore, this radical is able to oxidize a wide variety of organic compounds to yield $\mathrm{CO}_{2}, \mathrm{H}_{2} \mathrm{O}$ and inorganic ions from heteroatoms $[3,4]$. Hydrogen peroxide, a chemical source of $\bullet \mathrm{OH}$, can be produced electrochemically using gas diffusion electrodes (GDEs) [4-6] in which this oxidant is generated at the electrodegas-solution interface via the oxygen reduction reaction (ORR).

Under acid conditions, the oxygen can be reduced following two different paths: the first one involving four-electron transfer, $\mathrm{H}_{2} \mathrm{O}$ production, and the second one through a two-electron transfer, $\mathrm{H}_{2} \mathrm{O}_{2}$ electrogeneration [7]. According to Griffith, Pauling and Bridge models [8], the possible reaction routes and the number of electrons transferred during the oxygen reduction process are related to the different types of $\mathrm{O}_{2}$ adsorption on the catalytic surface. It is well known that amorphous carbon displays catalytic

\footnotetext{
* Corresponding author.

E-mail address: marcoslanza@iqsc.usp.br (M.R.V. Lanza).
}

activity to $\mathrm{H}_{2} \mathrm{O}_{2}$ production [5]. However, the treatment of the carbon or addition of organic and inorganic materials on this substrate can enable the ORR following a two-electron pathway with high selectivity and at low overpotential [9-11].

Tantalum oxide-based catalysts exhibit high oxygen reduction onset potential ( $\sim 0.95 \mathrm{~V}$ vs. SHE) and excellent stability under corrosive environments $[12,13]$. Furthermore, this oxide has acid sites [14], which promotes more hydrophilicity on the composite surface inducing more active sites for the catalytic redox reaction [15]. Therefore, in this study we investigate on the properties of $\mathrm{Ta}_{2} \mathrm{O}_{5} / \mathrm{C}$ for the electrocatalysis of oxygen reduction by rotating ring-disk electrode. The yield of $\mathrm{H}_{2} \mathrm{O}_{2}$ production and the energy consumed during the process were determined using a GDE either unmodified or modified with $\mathrm{Ta}_{2} \mathrm{O}_{5}$.

\section{Experimental}

\subsection{Preparation of electrocatalysts}

$\mathrm{Ta}_{2} \mathrm{O}_{5}$ nanoparticles supported on carbon black (Printex 6L carbon, Evonik) were prepared by thermal decomposition of a polymeric precursor solution (DPP) [16] using tantalum(V) ethoxide [ $\left(\mathrm{CH}_{3} \mathrm{CH}_{2} \mathrm{O}\right)_{5} \mathrm{Ta}$, Sigma-Aldrich] as the salt precursor. In a typical experiment, $\left(\mathrm{CH}_{3} \mathrm{CH}_{2} \mathrm{O}\right)_{5} \mathrm{Ta}$, citric acid and ethylene glycol were mixed in molar ratio 1:10:40, respectively, and stirred with a mag- 
netic stirrer for 40 min at $60^{\circ} \mathrm{C}$. Carbon black was then added slowly to the mixture under stirring. The dispersion was heated in air at a rate of $2.5^{\circ} \mathrm{C} \mathrm{min}-1$ and finally held at $500^{\circ} \mathrm{C}$ for $30 \mathrm{~min}$. The catalyst was prepared with $5.0 \%(\mathrm{w} / \mathrm{w}) \mathrm{Ta} / \mathrm{C}$.

The upper temperature limit for the synthesis of nanoparticles on the carbon surface was determined by thermogravimetric analysis (TGA) of sample of carbon black using a DuPont Instruments model TGA 2950 analyzer.

In addition, carbon black was treated following the same procedure described above but without adding metallic precursor in the first step. This procedure was performed in order to verify the influence of the polymeric precursor method in the carbon catalytic activity for the ORR.

\subsection{Chemical physical characterization of electrocatalysts}

The morphological and chemical characterization were performed by transmission electron microscopy (TEM) and X-ray photoelectron spectroscopy (XPS). The TEM images were recorded using a $200 \mathrm{kV}$ high resolution FEI Tecnai G2 F20 instrument. Xray photoelectron spectra were measured at a pressure of less than $10^{-7}$ Pa using a UNI-SPECS UHV system equipped with an $\mathrm{MgK} \alpha$ $\mathrm{X}$-ray source $(\mathrm{h} \nu=1253.6 \mathrm{eV})$ with the analyzer pass energy set at $10 \mathrm{eV}$. The inelastic background of the $\mathrm{C}(1 \mathrm{~s})$ and $\mathrm{O}(1 \mathrm{~s})$ electrons of the core-level spectra was subtracted using Shirley's method. The spectra were fitted without placing constraints using multiple Voigt profiles.

\subsection{Electrochemical characterization of electrocatalysts}

Electrochemical characterization were performed using a Metrohm-Autolab PGSTAT $128 \mathrm{~N}$ potentiostat/galvanostat and a Pine Instruments rotating ring-disk electrode (RRDE) system. The working electrode was prepared by dispersing $1 \mathrm{mg}$ of catalyst in $1 \mathrm{~mL}$ of water by sonication for $30 \mathrm{~min}$ and loading a $20 \mu \mathrm{L}$ sample of the resulting suspension onto a $5.6 \mathrm{~mm}$ diameter glassy carbon electrode. The layer of catalyst was dried slowly in air, following which a $20 \mu \mathrm{L}$ aliquot of an aqueous solution of Nafion ${ }^{\circledR}(0.05 \%)$ was transferred carefully to the microlayer surface. Experiments were carried out in a conventional electrochemical cell using Pt foil as counter electrode, an $\mathrm{Ag} / \mathrm{AgCl}$ electrode as reference electrode and an electrolyte solution comprising $0.1 \mathrm{~mol} \mathrm{~L}^{-1} \mathrm{~K}_{2} \mathrm{SO}_{4}$ at $\mathrm{pH}=2$, adjusted by $\mathrm{H}_{2} \mathrm{SO}_{4}$.

Cyclic voltammetry (CV) curves were recorded in $\mathrm{N}_{2}$-saturated electrolyte solution at a sweep rate of $10 \mathrm{mV} \mathrm{s}^{-1}$. The linear sweep voltammetry (LSV) curves were conducted in $\mathrm{N}_{2}$ and $\mathrm{O}_{2}$-saturated solution. The disk electrode was scanned at a rate of $5 \mathrm{mV} \mathrm{s}^{-1}$ while the ring potential was kept constant at $+1.0 \mathrm{~V}$. All the LSVs curves presented in this work were corrected by subtracting of the background current recorded in $\mathrm{N}_{2}$-satured solution.

\subsection{Generation of $\mathrm{H}_{2} \mathrm{O}_{2}$ in a gas diffusion electrode}

Based on the results obtained from the RRDE experiments, GDE with $3.4 \mathrm{~cm}^{2}$ exposed area were constructed with carbon black either unmodified or modified with Ta2O5 nanoparticles $(5.0 \%$ $(\mathrm{w} / \mathrm{w}) \mathrm{Ta} / \mathrm{C})$ and $20 \%(\mathrm{w} / \mathrm{w})$ of a $60 \%$ aqueous dispersion of DuPont Teflon ${ }^{\circledR}$ PTFE TE 3859 as described previously [6,7].

Electrochemical experiments were performed in a threeelectrode single compartment cell with the working electrode (GDE) located at the bottom of the cell and supplied with $\mathrm{O}_{2}$ at a pressure of 0.2 bar. In order to quantify the $\mathrm{H}_{2} \mathrm{O}_{2}$ produced during electrolysis, $0.5 \mathrm{~mL}$ samples of electrolyte were collected at appropriate time intervals, mixed with $4 \mathrm{~mL}$ aliquots of a solution of $\left(\mathrm{NH}_{4}\right)_{6} \mathrm{Mo}_{7} \mathrm{O}_{24}\left(2.4 \times 10^{-3} \mathrm{~mol} \mathrm{~L}^{-1}\right)$ in $0.5 \mathrm{~mol} \mathrm{~L}^{-1} \mathrm{H}_{2} \mathrm{SO}_{4}$ and absorption measured at $350 \mathrm{~nm}$. The amounts of $\mathrm{H}_{2} \mathrm{O}_{2}$ present in the samples were evaluated by reference to a standard calibration curve $[9,17]$.

\section{Results and discussion}

\subsection{Characterization of electrocatalysts}

The TGA analysis of carbon black (Fig. S1) represents the weight loss of a sample as a function of temperature. The small (2\%) reduction in weight observed on heating from $25^{\circ} \mathrm{C}$ to $\sim 500^{\circ} \mathrm{C}$ can be associated with the loss of water adsorbed on the carbon. However, heating to temperatures above $600^{\circ} \mathrm{C}$ give rise to a pronounced loss in weight of carbon black and it is fully degraded to $\mathrm{CO}_{2}$ at $700{ }^{\circ} \mathrm{C}$. These results provided an upper temperature limit (taken as $500^{\circ} \mathrm{C}$ ) for the thermal treatment employed in the synthesis of nanoparticles on the surface of carbon black.

TEM images of $\mathrm{Ta}_{2} \mathrm{O}_{5}$ on carbon black are shown in Fig. 1. These images show the good distribution of $\mathrm{Ta}_{2} \mathrm{O}_{5}$ nanoparticles over the carbon (Fig. 1A and B) with a particle size around $2.07 \pm 0.27 \mathrm{~nm}$ (Fig. 1C). The selective area diffraction pattern (SAED, Fig. 1D), with well-defined lattice planes, confirms the nanocrystalline structure of the $\mathrm{Ta}_{2} \mathrm{O}_{5}$ nanoparticles. The interplanar distance of $3.36 \AA$ and 3.63 Å correspond to the (0 15 ) and (0 13 ) planes (JCPDS\#27-1447), respectively. Furthermore, elemental mapping of Ta, $\mathrm{C}$ and $\mathrm{O}$ using energy dispersive X-ray analysis was undertaken (Fig. 1E-H and Fig. S2). The area of bright contrast correlates with the Ta signal map.

Fig. 2A and B shows the respective fitted high resolution XPS C (1s) spectra for carbon black before and after thermal treatment by polymeric precursor method. The four components present in the deconvoluted spectra are associated with the aromatic phase $\left(\mathrm{C}-\mathrm{C} \mathrm{sp}^{2}\right)$ centered at $284.3 \mathrm{eV}, \mathrm{C}-\mathrm{H}$ carbon at $285.4 \mathrm{eV}$ and the oxidized carbon groups in the form of carbonyl $(\mathrm{C}=\mathrm{O})$ at $287.3 \mathrm{eV}$ and carboxyl $(\mathrm{O}-\mathrm{C}=\mathrm{O})$ at $289.3 \mathrm{eV}$ [18]. The main component of the spectrum obtained prior to thermal treatment relates to the aromatic phase along with a small contribution from the oxygenated groups and a $\pi$ plasmon peak at the high energy tail $(\sim 291 \mathrm{eV})$. However, the strong oxidation processes associated with calcination at $500^{\circ} \mathrm{C}$ give rise to a marked reduction in the aromatic phase and an increase in the proportion of oxygenated groups. In fact, the oxygen concentration in the form of carbonyl and carboxyl increase from $9.2 \pm 0.4$ at.\% to $16.9 \pm 0.8$ at.\%. It is important to note that, according to the results obtained by TGA, the carbon black remains thermally stable at $500{ }^{\circ} \mathrm{C}$ and does not undergo combustion to $\mathrm{CO}_{2}$.

The main components of the deconvoluted XPS O (1s) spectrum of treated carbon black (Fig. 2C) can be attributed to $\mathrm{C}=\mathrm{O}$ at $532.5 \mathrm{eV}$ and $\mathrm{O}-\mathrm{C}=\mathrm{O}$ at $533.9 \mathrm{eV}$ [18], confirming the presence of groups previously identified in the $C(1 \mathrm{~s})$ spectrum. An additional small component at low binding energy $(530.6 \mathrm{eV})$ is present in the deconvoluted XPS O (1s) spectrum of $\mathrm{Ta}_{2} \mathrm{O}_{5} / \mathrm{C}$ electrocatalyst (Fig. 2D), and it is related to O-Ta bonds [18] of $\mathrm{Ta}_{2} \mathrm{O}_{5}$ nanoparticles embedded in the carbon matrix.

Fig. 3 shows the $\mathrm{Ta}(4 \mathrm{f})$ spectrum for the $\mathrm{Ta}_{2} \mathrm{O}_{5} / \mathrm{C}$ electrocatalyst. The spectrum is fitted with very good precision by only one spinorbit doublet at a fixed separation of $1.8 \mathrm{eV}$. The binding energy of the Ta $4 \mathrm{f} 7 / 2$ centered at $27.1 \mathrm{eV}$ corresponds to the $\mathrm{Ta}_{2} \mathrm{O}_{5}$ phase [18]. This result, combined with the SAED pattern, provides a clear evidence for the presence of $\mathrm{Ta}_{2} \mathrm{O}_{5}$ on the carbon surface.

\subsection{Study of the reduction reaction of molecular oxygen}

Fig. 4 shows the cyclic voltammograms obtained for uncoated disk electrode (glassy carbon), treated and non-treated carbon black and $\mathrm{Ta}_{2} \mathrm{O}_{5} / \mathrm{C}$ electrodes in $\mathrm{N}_{2}$-saturated solution. The voltammogram of the carbon black shows no peak of redox transition 

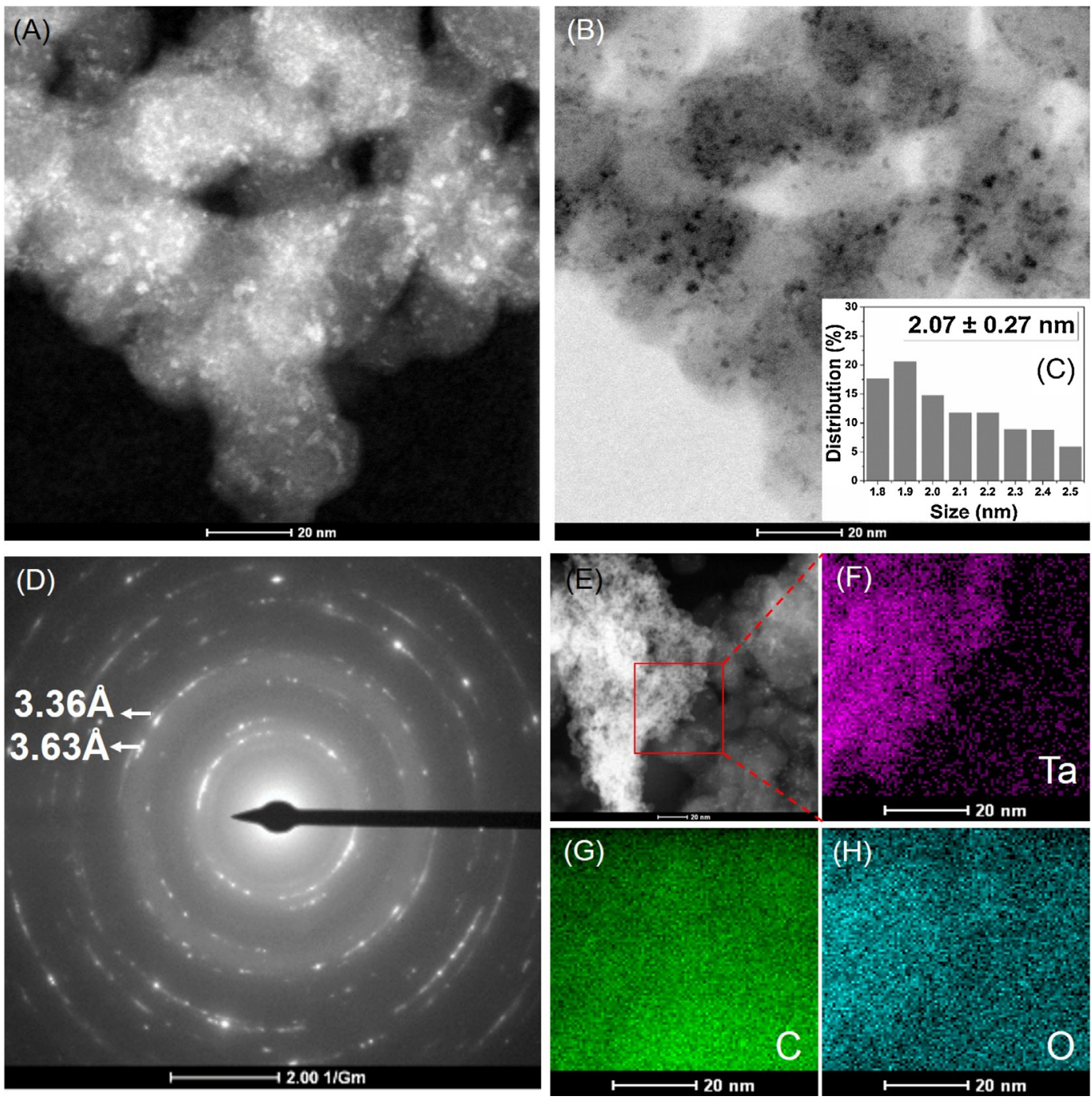

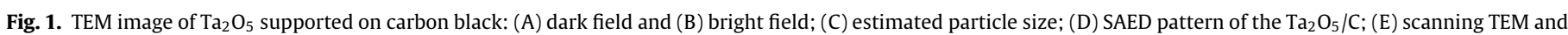
elemental mapping images of $(\mathrm{F}) \mathrm{Ta},(\mathrm{G}) \mathrm{C}$ and $(\mathrm{H}) \mathrm{O}$.

(Fig. 4, plot b). However, a blurred peak at ca. $+0.1 \mathrm{~V}$ is observed in the CV after thermal treatment of the carbon (Fig. 4, plot $\mathrm{c}$ and inserted). This redox transition can be attributed to the increase of oxygenated groups on the treated carbon surface in agreement with XPS analysis [6,19-21].

The voltammogram for the $\mathrm{Ta}_{2} \mathrm{O}_{5} / \mathrm{C}$ electrode (Fig. 4, plots d) shows a blurred peak from $+0.4 \mathrm{~V}$ to $0.0 \mathrm{~V}$. This redox transition can be assigned to the reduction of $\mathrm{Ta}_{2} \mathrm{O}_{5}$ to metallic Ta (Eq. (1)) in agreement with potential-pH equilibrium diagram for tantalumwater, at $25^{\circ} \mathrm{C}$, described by Pourbaix [22] and the presence of oxygenated groups on the catalytic surface [19].

$\mathrm{Ta}_{2} \mathrm{O}_{5}+10 \mathrm{H}^{+}+10 \mathrm{e}^{-} \rightleftarrows 2 \mathrm{Ta}+5 \mathrm{H}_{2} \mathrm{O}$

The variation in current values at potentials lower than $-0.4 \mathrm{~V}$ is related to the start of the hydrogen evolution reaction arising from the reduction of $\mathrm{H}^{+}$ions present in solution.

In order to verify the ORR pathway of the carbon black, treated carbon and $\mathrm{Ta}_{2} \mathrm{O}_{5} / \mathrm{C}$ catalysts, the formation of $\mathrm{H}_{2} \mathrm{O}_{2}$ (ring current $-\mathrm{I}_{\text {ring }}$ ) was monitored using a RRDE system. As shown in Fig. 5, the treated carbon black displays higher ring current than the non-treated carbon demonstrating that the increase in the oxygen-containing functional groups on the carbon surface (XPS data) makes the catalyst more selective for $\mathrm{H}_{2} \mathrm{O}_{2}$ electrogeneration.
Linear voltammetric profiles of the $\mathrm{Ta}_{2} \mathrm{O}_{5} / \mathrm{C}$ catalyst show oxidation currents of hydrogen peroxide $\left(\mathrm{I}_{\text {ring }}\right)$ higher than those of carbon black, suggesting higher $\mathrm{H}_{2} \mathrm{O}_{2}$ electrogeneration in the presence of $\mathrm{Ta}_{2} \mathrm{O}_{5}$. Furthermore, this catalyst exhibit overpotential $97 \mathrm{mV}$ lower than that of carbon black for the reduction $\mathrm{O}_{2}$ to $\mathrm{H}_{2} \mathrm{O}_{2}$, thus enabling the two-electron ORR pathway at lower overpotential. The shift in the ORR onset potential in the presence of $\mathrm{Ta}_{2} \mathrm{O}_{5}$ can be explain by the high ORR onset potential of this oxide [12,13].

The current efficiency for hydrogen peroxide formation $\left(\mathrm{I}\left(\mathrm{H}_{2} \mathrm{O}_{2}\right) \%\right)$ and the number of electrons transferred $\left(\mathrm{n}_{\mathrm{t}}\right)$ during the oxygen reduction were determined quantitatively using the following equations [23]:

$$
\begin{aligned}
& I\left(\mathrm{H}_{2} \mathrm{O}_{2}\right) \%=\frac{200 \cdot I_{r} / N}{I_{d}+I_{r} / N} \\
& n_{t}=\frac{4 \times I_{d}}{I_{d}+I_{r} / N}
\end{aligned}
$$

where $I_{r}$ is the ring current, $I_{d}$ is the disk current and $N$ is the current collection efficiency of the Pt ring $(\mathrm{N}=0.37)$. The values of $\mathrm{I}_{2}\left(\mathrm{H}_{2} \mathrm{O}_{2}\right) \%$ and $n_{t}$ obtained for the electrocatalysts employed in this study are shown in Table 1.

According to Table 1 , the $\mathrm{H}_{2} \mathrm{O}_{2}$ production on carbon black is $65.3 \%$ whereas on treated carbon black is $74.5 \%$. Moreover, the 

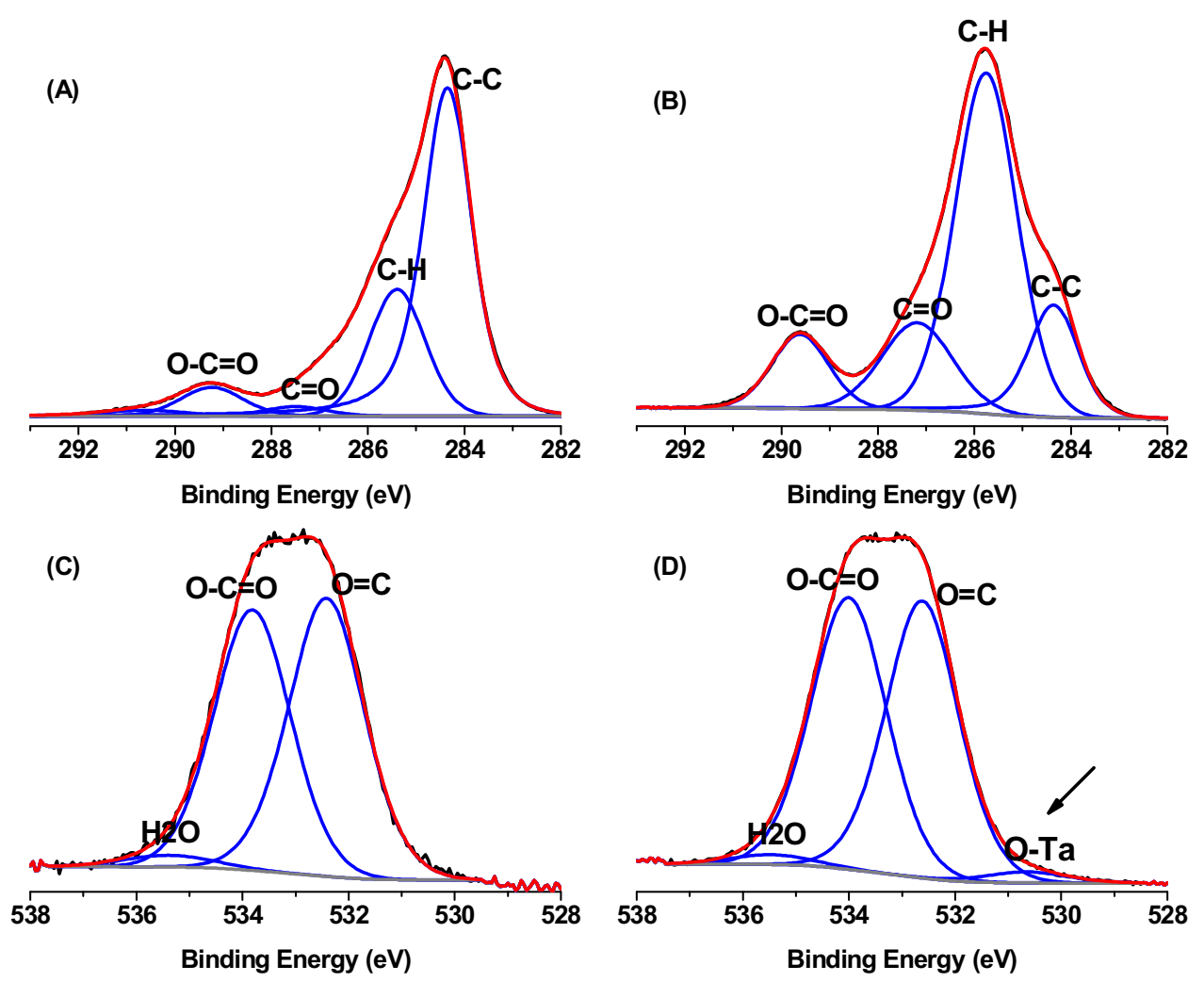

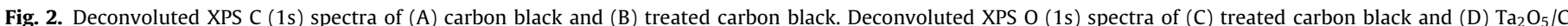
electrocatalyst $(5.0 \% \mathrm{w} / \mathrm{w} \mathrm{Ta} / \mathrm{C})$.

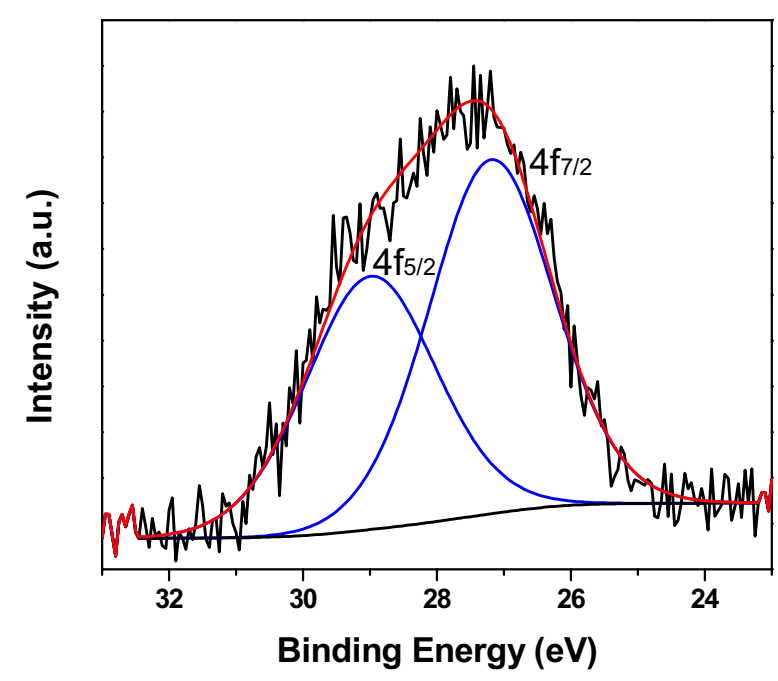

Fig. 3. Deconvoluted Ta (4f) spectrum of $\mathrm{Ta}_{2} \mathrm{O}_{5} / \mathrm{C}$ electrocatalyst $(5.0 \% \mathrm{w} / \mathrm{w} \mathrm{Ta} / \mathrm{C})$.

Table 1

Current efficiency for hydrogen peroxide formation and number of electrons transferred during the ORR. The values presented were calculated over the potential range from $-0.3 \mathrm{~V}$ to $-0.5 \mathrm{~V}$ (region of mixed control of the LSVs).

\begin{tabular}{llll}
\hline & Carbon black & Treated carbon black & $\mathrm{Ta}_{2} \mathrm{O}_{5} / \mathrm{C}(5.0 \%(w / w) \mathrm{Ta} / \mathrm{C})$ \\
\hline $\mathrm{I}\left(\mathrm{H}_{2} \mathrm{O}_{2}\right) \%$ & 65.3 & 74.5 & 83.2 \\
$\mathrm{nt}$ & 2.7 & 2.5 & 2.3 \\
\hline
\end{tabular}

presence of $\mathrm{Ta}_{2} \mathrm{O}_{5}$ increase the selectivity for $\mathrm{H}_{2} \mathrm{O}_{2}$ electrogeneration to $83.2 \%$. Therefore, the high selectivity to $\mathrm{H}_{2} \mathrm{O}_{2}$ production on $\mathrm{Ta}_{2} \mathrm{O}_{5} / \mathrm{C}$ catalyst is atttributed to the synergistic effect between the $\mathrm{Ta}_{2} \mathrm{O}_{5}$ nanoparticles and the oxygen functional groups on the sur-

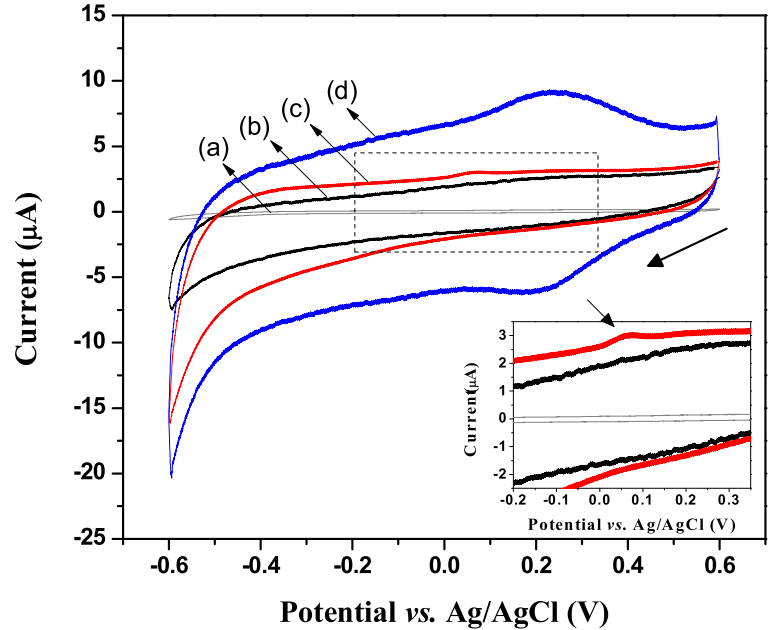

Fig. 4. Cyclic voltammetric profiles of (a) uncoated disk electrode (glassy carbon), (b) carbon black (c) treated carbon black and (d) $\mathrm{Ta}_{2} \mathrm{O}_{5} / \mathrm{C}$ electrodes recorded in $\mathrm{N}_{2}$-saturated solution $0.1 \mathrm{~mol} \mathrm{~L}^{-1} \mathrm{~K}_{2} \mathrm{SO}_{4}$ at $\mathrm{pH}=2$, adjusted by $\mathrm{H}_{2} \mathrm{SO}_{4}$, at a scan rate of $10 \mathrm{mVs}^{-1}$.

face of the material. In this context, the presence of $\mathrm{Ta}_{2} \mathrm{O}_{5}$ promotes RRO via electrochemical/chemical mechanism. In the electrochemical stage, $\mathrm{Ta}_{2} \mathrm{O}_{5}$ is reduced in the cathode sweep [22]. Then, the oxygen molecule absorbs on the catalyst surface as described in the Pauling model [8] in which oxygen is reduced causing the oxidation of tantalum (chemical step). Additionally, the presence of oxygen functional groups on the material surface act as electroactive sites promoting the transfer of electrons for the ORR [19]. 


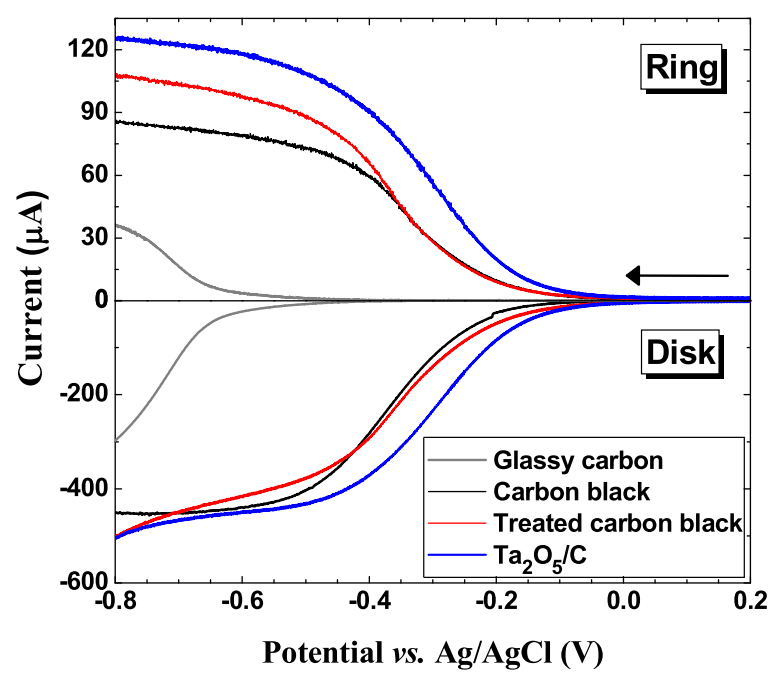

Fig. 5. Steady state polarization curves for the ORR determined using RRDE system of uncoated disk electrode, carbon black, treated carbon black and $\mathrm{Ta}_{2} \mathrm{O}_{5} / \mathrm{C}(5.0 \%$ $(\mathrm{w} / \mathrm{w}) \mathrm{Ta} / \mathrm{C}$ ) catalysts. The electrolyte was $0.1 \mathrm{~mol} \mathrm{~L}^{-1} \mathrm{~K}_{2} \mathrm{SO}_{4}$ at $\mathrm{pH}=2$, adjusted by $\mathrm{H}_{2} \mathrm{SO}_{4}$, the scan rate was $5 \mathrm{mV} \mathrm{s}^{-1}$, the RRDE rotation $(\omega)$ was $900 \mathrm{rpm}$ and the ring potential $\left(\mathrm{E}_{\mathrm{r}}\right)$ was $+1.0 \mathrm{~V}$. The $\mathrm{O}_{2}$ reduction waves were subtracted for the background current recorded in $\mathrm{N}_{2}$-satured electrolyte.

\subsection{Study of $\mathrm{H}_{2} \mathrm{O}_{2}$ generation in the gas diffusion electrode}

The results obtained using RRDE system revealed that the addition of $\mathrm{Ta}_{2} \mathrm{O}_{5}$ on carbon black increase the selectivity for the $\mathrm{H}_{2} \mathrm{O}_{2}$ electrogeneration (Fig. 5). In order to study the formation of $\mathrm{H}_{2} \mathrm{O}_{2}$ by this electrocatalyst in more detail, it was quantify the generation of hydrogen peroxide in solution using a gas diffusion electrode. The ORR on GDE occurs at the solid-liquid-gas interface, and allows the generation of $\mathrm{H}_{2} \mathrm{O}_{2}$ in situ. In contrast to planar electrodes, GDEs do not suffer limitations imposed by the concentration of $\mathrm{O}_{2}$ gas in the bulk of the solution or by the diffusion of molecules to the electrode surface.

The $\mathrm{H}_{2} \mathrm{O}_{2}$ detection in GDE was performed by sampling the electrolyte and the $\mathrm{H}_{2} \mathrm{O}_{2}$ electrogeneration at constant potential was quantified spectrophotometrically. Fig. 6 shows the electrogeneration of $\mathrm{H}_{2} \mathrm{O}_{2}$ as a function of time of electrolysis using GDEs constructed with carbon black either unmodified or modified with $\mathrm{Ta}_{2} \mathrm{O}_{5}$ nanoparticles and operated with applied potentials in the range $-0.5 \mathrm{~V}$ to $-1.4 \mathrm{~V}$ vs $\mathrm{Ag} / \mathrm{AgCl}$.

For the GDE constructed with carbon black (Fig. 6A), raising the applied potential from $-0.5 \mathrm{~V}$ to $-1.1 \mathrm{~V}$ v $\mathrm{Ag} / \mathrm{AgCl}$ promotes incremental increases in the concentration of $\mathrm{H}_{2} \mathrm{O}_{2}$ formed. However, although the highest amount of $\mathrm{H}_{2} \mathrm{O}_{2}\left(19.1 \mathrm{mg} \mathrm{L}^{-1}\right)$ is recorded after $120 \mathrm{~min}$ of electrolysis at a potential of $-1.1 \mathrm{~V}$, this value must be considered equivalent to that of $19.0 \mathrm{mg} \mathrm{L}^{-1}$ obtained after 120 min electrolysis at $-1.0 \mathrm{~V}$ given that the GDE shows a variation of $6.3 \pm 0.8 \%$ according to Reis et al. [24]. At more negative potentials, the electrogeneration of $\mathrm{H}_{2} \mathrm{O}_{2}$ decreases such that at $-1.4 \mathrm{~V}$ vs $\mathrm{Ag} / \mathrm{AgCl}$ only $11.6 \mathrm{mg} \mathrm{L}^{-1}$ of hydrogen peroxide is formed after 120 min of electrolysis.

A similar behavior is observed for the GDE constructed with $\mathrm{Ta}_{2} \mathrm{O}_{5} / \mathrm{C}$ (Fig. 6B), in which case increasing the applied potential from $-0.5 \mathrm{~V}$ vs $\mathrm{Ag} / \mathrm{AgCl}$ lead to increases $\mathrm{H}_{2} \mathrm{O}_{2}$ production up to a maximum value of $27.9 \mathrm{mg} \mathrm{L}^{-1}$ attained after $120 \mathrm{~min}$ of electrolysis at $-1.0 \mathrm{~V}$. At more negative potentials, the electrogeneration of $\mathrm{H}_{2} \mathrm{O}_{2}$ decreases with only $9.4 \mathrm{mg} \mathrm{L}^{-1}$ of hydrogen peroxide being formed after $120 \mathrm{~min}$ of electrolysis at $-1.4 \mathrm{~V}$.

Plots showing the final concentration of $\mathrm{H}_{2} \mathrm{O}_{2}$ achieved at the end of the experiment as a function of the potential applied to the
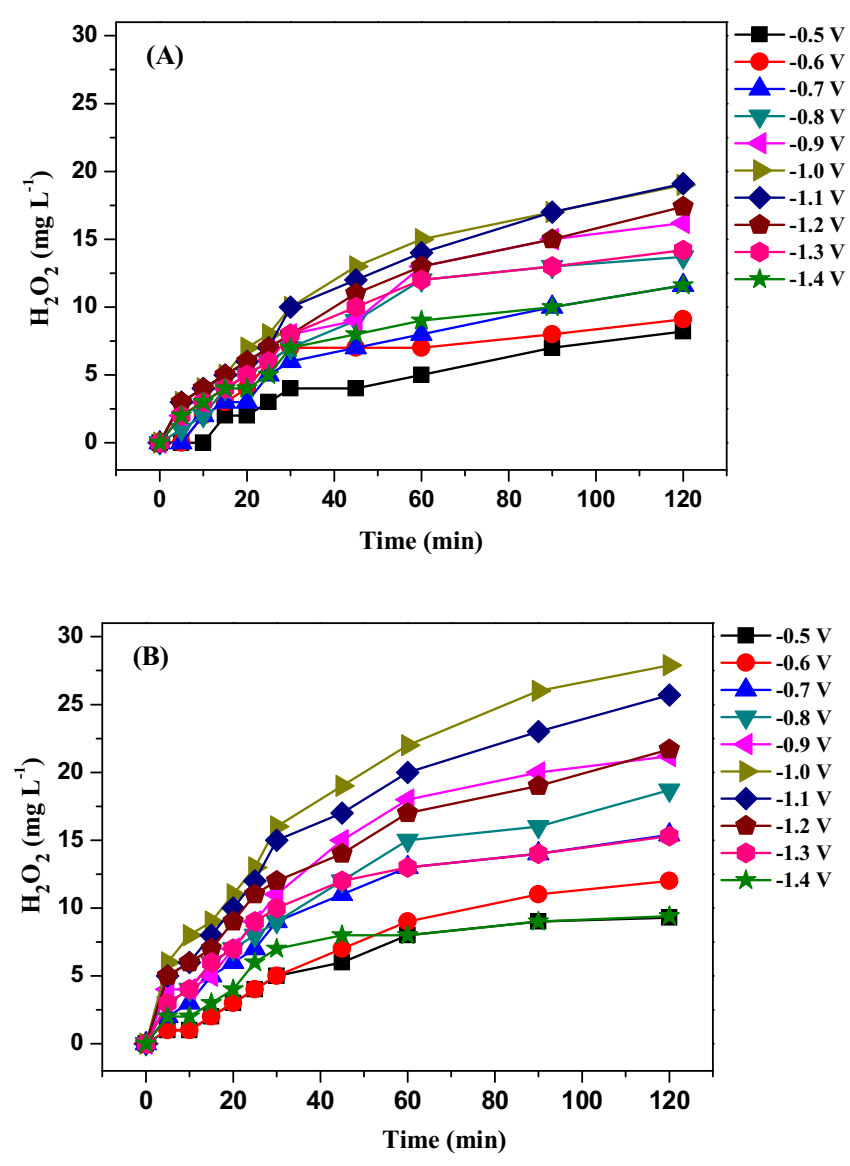

Fig. 6. $\mathrm{H}_{2} \mathrm{O}_{2}$ electrogeneration in $400 \mathrm{~mL}$ of $0.1 \mathrm{~mol} \mathrm{~L}^{-1} \mathrm{~K}_{2} \mathrm{SO}_{4}$ at $\mathrm{pH}=2$, adjusted by $\mathrm{H}_{2} \mathrm{SO}_{4}$, and different applied potentials using $\mathrm{GDE}\left(3.4 \mathrm{~cm}^{2}\right.$ exposed area) constructed with (A) unmodified carbon black and (B) carbon black modified with $\mathrm{Ta}_{2} \mathrm{O}_{5}$ nanoparticles $\left(\mathrm{Ta}_{2} \mathrm{O}_{5} / \mathrm{C}\right)$.

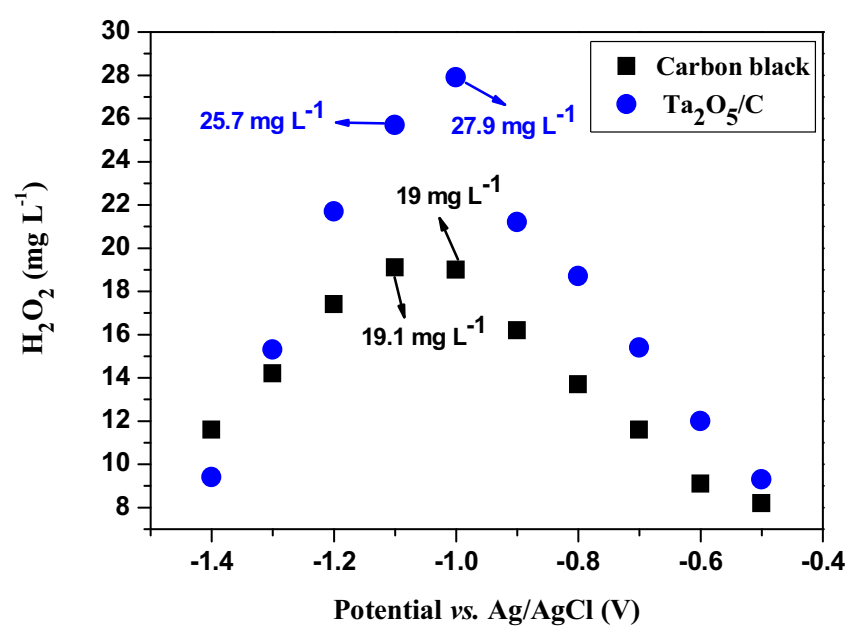

Fig. 7. Final concentrations of $\mathrm{H}_{2} \mathrm{O}_{2}$ obtained in $400 \mathrm{~mL}$ of $0.1 \mathrm{~mol} \mathrm{~L}^{-1} \mathrm{~K}_{2} \mathrm{SO}_{4}$ at $\mathrm{pH}=2$, adjusted by $\mathrm{H}_{2} \mathrm{SO}_{4}$, following 120 min of electrolysis using GDE constructed with carbon black and GDE constructed with carbon black modified with $\mathrm{Ta}_{2} \mathrm{O}_{5}$ nanoparticles.

unmodified and modified GDE (Fig. 7) confirm that the electrogeneration of hydrogen peroxide is more efficient with the $\mathrm{Ta}_{2} \mathrm{O}_{5} / \mathrm{C}$ electrode over the potential range from -0.5 to $-1.4 \mathrm{~V} v \mathrm{sg} / \mathrm{AgCl}$. Moreover, the modified GDE generates a maximum concentration 
of $\mathrm{H}_{2} \mathrm{O}_{2}\left(27.9 \mathrm{mg} \mathrm{L}^{-1}\right)$ at $-1.0 \mathrm{~V}$, a value that is $46.1 \%$ higher than the maximum level (19.1 $\mathrm{mg} \mathrm{L}^{-1}$ ) produced by the unmodified GDE at $-1.1 \mathrm{~V}$.

As may be observed in Fig. 6, the change in $\mathrm{H}_{2} \mathrm{O}_{2}$ concentration is practically linear during the first minutes of electrolysis indicating that the ORR follows zero-order kinetics. However, modifications in $\mathrm{H}_{2} \mathrm{O}_{2}$ concentration are related to the cumulative effects of all reactions that occur in parallel with the ORR on the cathode and anode. Thus, the electrosynthesis of $\mathrm{H}_{2} \mathrm{O}_{2}$ at a GDE is considered to follow global pseudo-zero-order kinetics $[9,24,25]$ and the global rate constant $\mathrm{k}$ ( $\mathrm{mg} \mathrm{L}^{-1} \mathrm{~min}^{-1}$ ) can be calculated from the angular coefficients of plots of $\mathrm{H}_{2} \mathrm{O}_{2}$ concentration $\left(\mathrm{mg} \mathrm{L}^{-1}\right)$ vs time (min) considering only the first $30 \mathrm{~min}$ of each experiment. The global rate constant for the formation of $\mathrm{H}_{2} \mathrm{O}_{2}$ (Fig. S5) increases as the applied potential increases from $-0.5 \mathrm{~V}$ vs $\mathrm{Ag} / \mathrm{AgCl}$, and attains a maximum of $6.9 \mathrm{mg} \mathrm{L}^{-1} \mathrm{~min}^{-1}$ at $-1.1 \mathrm{~V}$ with the unmodified GDE and a maximum of $7.6 \mathrm{mg} \mathrm{L}^{-1} \mathrm{~min}^{-1}$ at $-1.0 \mathrm{~V}$ with the modified GDE. At potentials more negative than $-1.1 \mathrm{~V}$, values of $\mathrm{k}$ decrease with increasing applied potential for both electrodes. According to Valim et al. [6], decreases in $\mathrm{k}$ at applied potentials higher than $-1.1 \mathrm{~V}$ are associated with increases activity of the ORR by the fourelectron transfer mechanism and the consequent decreases in $\mathrm{H}_{2} \mathrm{O}_{2}$ formation via the two-electron pathway, as verified by the results shown in Fig. 7.

The energy consumption EC $\left(\mathrm{kWh} \mathrm{kg}^{-1}\right)$ for the $\mathrm{H}_{2} \mathrm{O}_{2}$ electrogeneration [24] plotted as a function of the potential applied to the unmodified and modified GDEs is showed in Supporting information (Fig. S6). Both electrodes exhibit similar behavior up to a potential of $-1.1 \mathrm{~V} v s \mathrm{Ag} / \mathrm{AgCl}$, but show greater variation at more negative potentials. $\mathrm{EC}$, which is directly proportional to cell current and potential, increase incrementally up to $-1.1 \mathrm{~V}$ as the concentration of $\mathrm{H}_{2} \mathrm{O}_{2}$ generated gradually increase. However, at potentials higher than $-1.1 \mathrm{~V}$, the $\mathrm{H}_{2} \mathrm{O}_{2}$ formation decreases for both electrodes such that the EC values per unit weight of peroxide formed increase markedly, a behavior that has been described previously in the literature $[24,25]$. In the present study, production of $1 \mathrm{~kg}$ of $\mathrm{H}_{2} \mathrm{O}_{2}$ at the maximum concentration attainable (19.1 $\mathrm{mg} \mathrm{L}^{-1}$ at $-1.1 \mathrm{~V}$ ) with an unmodified GDE would require $18.8 \mathrm{kWh}$. However, with the modified GDE, generation of $1 \mathrm{~kg}$ of $\mathrm{H}_{2} \mathrm{O}_{2}$ at maximum concentration attainable $\left(27.9 \mathrm{mg} \mathrm{L}^{-1}\right.$ at $\left.-1.0 \mathrm{~V}\right)$ would require only $15 \mathrm{kWh}$.

The high catalytic activity observed with the $\mathrm{Ta}_{2} \mathrm{O}_{5} / \mathrm{C}$ electrode can be attributed to the transfer of electrons from $\mathrm{Ta}_{2} \mathrm{O}_{5}$ to $\mathrm{O}_{2}$ related to a redox transition in the oxygen reduction region, and to the presence of oxygenated groups on the modified carbon surface (Fig. 2). In this electrocatalyst, the oxygen molecule probably couple to the electrode surface according to the process described by Pauling [8] in which the weak adsorption of $\mathrm{O}_{2}$ to the metal $[26,27]$ hinders breaking of the $\mathrm{O}-\mathrm{O}$ bond resulting in the $\mathrm{H}_{2} \mathrm{O}_{2}$ formation as the final product.

\section{Conclusions}

$\mathrm{Ta}_{2} \mathrm{O}_{5}$ nanoparticles on carbon black were prepared by thermal decomposition of a polymeric precursor solution. In addition, carbon black was treated in order to verify the influence of the polymeric precursor method in the carbon catalytic activity for the ORR. The current efficiency for $\mathrm{H}_{2} \mathrm{O}_{2}$ electrogeneration on $\mathrm{Ta}_{2} \mathrm{O}_{5} / \mathrm{C}$ catalyst is $83.2 \%$. The carbon black exhibits an $\mathrm{I}\left(\mathrm{H}_{2} \mathrm{O}_{2}\right) \%$ of $65.3 \%$ whereas the treated carbon displays $74.5 \%$ yield of $\mathrm{H}_{2} \mathrm{O}_{2}$ electrogeneration. The high selectivity to $\mathrm{H}_{2} \mathrm{O}_{2}$ production on $\mathrm{Ta}_{2} \mathrm{O}_{5} / \mathrm{C}$ catalyst is attributed to the synergistic effect between the $\mathrm{Ta}_{2} \mathrm{O}_{5}$ nanoparticles and the oxygen functional groups on the surface of the material. Based on the results obtained in the RRDE system, the $\mathrm{H}_{2} \mathrm{O}_{2}$ electrogeneration was monitored in detail using a
GDE ( $3.4 \mathrm{~cm}^{2}$ exposed area) constructed with carbon black either unmodified or modified with $\mathrm{Ta}_{2} \mathrm{O}_{5}$ nanoparticles. The results confirm the generation behavior observed with RRDE in that the modified GDE produces $27.9 \mathrm{mg} \mathrm{L}^{-1}$ of $\mathrm{H}_{2} \mathrm{O}_{2}$, while the unmodified GDE generates $19.1 \mathrm{mg} \mathrm{L}^{-1}$ of $\mathrm{H}_{2} \mathrm{O}_{2}$. Therefore, the addition of $\mathrm{Ta}_{2} \mathrm{O}_{5}$ on carbon give rise to an increase in $\mathrm{H}_{2} \mathrm{O}_{2}$ formation of almost $46.1 \%$. Furthermore, the $\mathrm{EC}$ for the $\mathrm{H}_{2} \mathrm{O}_{2}$ electrogeneration is lower in modified than in unmodified GDE $\left(15 \mathrm{~kW} \mathrm{~h} \mathrm{~kg}^{-1} \mathrm{vs}\right.$. $\left.18.8 \mathrm{~kW} \mathrm{~h} \mathrm{~kg}^{-1}\right)$. Thus, the high performance of the GDE $\left(\mathrm{Ta}_{2} \mathrm{O}_{5} / \mathrm{C}\right)$ renders it a viable alternative cathode in the electrochemical treatment of contaminated wastewaters.

\section{Acknowledgments}

The authors acknowledge the financial support of the Conselho Nacional de Desenvolvimento Científico e Tecnológico (CNPq-grants 163689/2015-6, 160507/2011-1, 143345/2011-7 and 470079/2013-4), the Fundação de Amparo à Pesquisa do Estado de São Paulo (FAPESP-grants 2011/14314-1) and the Coordenação de Aperfeiçoamento de Pessoal de Nível Superior (CAPES).

\section{Appendix A. Supplementary data}

Supplementary data associated with this article can be found, in the online version, at http://dx.doi.org/10.1016/j.apcata.2016.03. 013.

\section{References}

[1] G.V. Buxton, C.L. Greenstock, W.P. Helman, A.B. Ross, W. Tsang, J. Phys. Chem. Ref. Data 17 (1988) 513, http://dx.doi.org/10.1063/1.555805.

[3] W.H. Glaze, J.W. Kang, Ind. Eng. Chem. Res. 28 (1989) 1573-1580, http://dx. doi.org/10.1016/0368-1874(79)87235-4.

[4] E. Brillas, E. Mur, J. Casado, J. Electrochem. Soc. 143 (1996) L49-L53.

[5] M.H.M.T. Assumpção, R.F.B. De Souza, D.C. Rascio, J.C.M. Silva, M.L. Calegaro, I. Gaubeur, et al., Carbon N. Y. 49 (2011) 1842-2851.

[6] R.B. Valim, R.M. Reis, P.S. Castro, A.S. Lima, R.S. Rocha, M. Bertotti, et al., Carbon N. Y. 61 (2013) 236-244, http://dx.doi.org/10.1016/j.carbon.2013.04.100.

[7] E. Yeager, Electrochim. Acta 29 (1984) 1527-1537, http://dx.doi.org/10.1016/ 0013-4686(84)85006-9.

[8] B.E. Conway, J.O.M. Bockris, E. Yeager, S.U.M. Kham, R.E. White, Comprehensive Treatise of Electrochemistry, vol. 7, Kinetics and Mechanisms of Electrode Processes, New York (1983) ISBN: 978-1-4613-3586-3 (Print) 978-1-4613-3584-9 (Online).

[9] J.C. Forti, R.S. Rocha, M.R.V. Lanza, R. Bertazzoli, J. Electroanal. Chem. 601 (2007) 63-67, http://dx.doi.org/10.1016/j.jelechem.2006.10.023.

[10] F. Xu, T. Song, Y. Xu, Y. Chen, S. Zhu, S. Shen, J. Rare Earths 27 (2009) 128-133, http://dx.doi.org/10.1016/S1002-0721(08)60206-9.

[11] S. Marcotte, D. Villers, N. Guillet, L. Roue, J.P. Dodelet, Electrochim. Acta 50 (2004) 179-188.

[12] T. Oh, J.Y. Kim, Y. Shin, M. Engelhard, K.S. Weil, J. Power Sources 196 (2011) 6099-6103, http://dx.doi.org/10.1016/j.jpowsour.2011.03.058.

[13] J.Y. Kim, T.K. Oh, Y. Shin, J. Bonnett, K.S. Weil, Int. J. Hydrogen Energy 36 (2011) 4557-4564, http://dx.doi.org/10.1016/j.ijhydene.2010.05.016.

[14] T. Ushikubo, K. Wada, Appl. Catal. 67 (1990) 25-38, http://dx.doi.org/10.1016 S0166-9834(00)84429-2.

[15] V.S. Antonin, M.H.M.T. Assumpcao, J.C.M. Silva, L.S. Parreira, M.R.V. Lanza, M.C. Santos, Electrochim. Acta 109 (2013) 245-251, http://dx.doi.org/10. 1016/j.electacta.2013.07.078.

[16] M.P. Pechini, N. Adams, Method of preparating lead and alkaline earth titanates and niobates and coating method using the same to form a capacitor, US Patent 3330697 (1967).

[17] W.R.P. Barros, P.C. Franco, J.R. Steter, R.S. Rocha, M.R.V. Lanza, J. Electroanal. Chem. 722-723 (2014) 46-53, http://dx.doi.org/10.1016/j.jelechem.2014.03. 027.

[18] A.V. Naumkin, A. Kraut-Vass, S.W. Gaarenstroom, C.J. Powell, NIST X-ray Photoelectron Spectroscopy Database. NIST Standard Database 20, Version 4.1, htttp:/srdata.nist.gov/XPS/.

[19] J.F. Carneiro, M.J. Paulo, M. Siaj, A.C. Tavares, M.R.V. Lanza, J. Catal. 332 (2015) 51-61, http://dx.doi.org/10.1016/j.jcat.2015.08.027.

[20] A. Wang, A. Bonakdarpour, D.P. Wilkinson, E. Gyenge, Electrochim. Acta 66 (2012) 222-229, http://dx.doi.org/10.1016/j.electacta.2012.01.086.

[21] G. Zhang, F. Yang, M. Gao, L. Liu, J. Phys. Chem. C 112 (2008) 8957-8962, http://dx.doi.org/10.1021/jp800757v.

[22] M. Pourbaix, Atlas of Electrochemical Equilibria in Aqueous Solutions, 2nd ed. Texas, USA (1974) ISBN-13: 978-0915567980. ISBN-10: 0915567989. 
[23] U.A. Paulus, T.J. Schmidt, H.A. Gasteiger, R.J. Behm, J. Electroanal. Chem. 495 (2001) 134-145, http://dx.doi.org/10.1016/S0022-0728(00)00407-1.

[24] R.M. Reis, A.A.G.F. Beati, R.S. Rocha, M.H.M.T. Assumpção, M.C. Santos, R. Bertazzoli, et al., Ind. Eng. Chem. Res. 51 (2012) 649-654, http://dx.doi.org/10. 1021 /ie201317u.

[25] W.R.P. Barros, R.M. Reis, R.S. Rocha, M.R.V. Lanza, Electrochim. Acta 104 (2013) 12-18, http://dx.doi.org/10.1016/j.electacta.2013.04.079.
[26] J.R. Kitchin, J.K. Nørskov, M.A. Barteau, J.G. Chen, J. Chem. Phys. 120 (2004) 10240-10246, http://dx.doi.org/10.1063/1.1737365.

[27] J. Zhang, M.B. Vukmirovic, Y. Xu, M. Mavrikakis, R.R. Adzic, Angew. Chem. Int. Ed. 44 (2005) 2132-2135, http://dx.doi.org/10.1002/anie.200462335. 